\title{
Characteristics and attitudes of small-scale vegetable farmers in Chile
}

\author{
Sofia Boza $^{1 *}$ Maruja Cortes ${ }^{2}$ (D) Carmen Prieto ${ }^{3}$ (DD \\ Tomás Francisco Muñoz Eulogio ${ }^{1}$ (D) Marcos Mora $^{1}$ (D
}

${ }^{1}$ Department of Rural Management and Innovation, Faculty of Agricultural Sciences, University of Chile, 8820808, La Pintana, Santiago, Chile. E-mail: sofiaboza@u.uchile.cl. "Corresponding author.

${ }^{2}$ National Institute of Agricultural Research (INIA), Santiago, Chile.

${ }^{3}$ Department of Agro-Industry and Enology, Faculty of Agricultural Sciences, University of Chile, Santiago, Chile.

\begin{abstract}
An adequate supply of fresh, high quality and accessible vegetables is essential for a healthy food system. In Latin America, these are mostly produced by smallholder farmers. The objective of this research was to characterize the productive and commercial development of small-scale vegetable growers and to further understand and explain their attitudes on their business. A total of 335 farmers in Central Chile area were surveyed. The data was processed using descriptive and multivariate techniques. Results showed that farmers have a positive self-assessment of their technical performance, production quality and the contribution of farming to their household income. They express uncertainty about the future, as well as some disappointment with the prices they receive for their produce and their access to public support programs. There are significant differences between farmers within the sample; however, which allow two distinct clusters to be identified: "conformist" (69.05\%) and "critical" (30.95\%). These results suggested that these small-scale vegetable growers have certain generalizable attitudes and other divergent. The differences in attitudes coincide with differences in objective characteristics, including age, education, farm size and technology.
\end{abstract}

Key words: vegetable growing, attitudes, clusters, small-scale farmers, Chile.

Características e atitudes de pequenos agricultores de hortaliças no Chile

RESUMO: O fornecimento de vegetais frescos, de qualidade e acessíveis, são essenciais para um sistema alimentar saudável. Na América Latina, essa produção está principalmente nas mãos dos pequenos agricultores. O objetivo desta pesquisa é caracterizar o desenvolvimento produtivo e comercial de pequenos produtores de hortaliças e entender e explicar melhor suas atitudes em relação à atividade. No total, foram pesquisados 335 agricultores no centro do Chile. Os dados coletados foram processados usando técnicas descritivas e multivariadas. Como resultados, se encontraram uma avaliação geral positiva do desempenho técnico, da qualidade da produção e da contribuição para a renda familiar, embora acompanhada de uma incerteza sobre o futuro. Os entrevistados expressaram decepções sobre alguns aspectos, como preço de venda e acesso a programas de apoio público. No entanto, existem diferenças significativas na amostra que permitem a identificação de dois grupos: "conformistas" (69,05\%) e "crítico" (30,95\%). Esses resultados sugerem que, no caso analisado, os pequenos produtores de hortaliças têm certas atitudes generalizáveis e outras divergentes. As diferenças de atitudes são coincidentes com as características objetivas, como idade, escolaridade, tamanho da fazenda e tecnologia.

Palavras-chave: horticultura, atitudes, conglomerados, pequena agricultura, Chile.

\section{INTRODUCTION}

It is estimated that $84 \%$ of the farms worldwide are small-scale farms, defined as under two hectares in size, which occupy only $12 \%$ of the total agricultural land (LOWDER et al., 2016). This unequal distribution of land is especially pronounced in Latin America, with a Gini index of 0.79 (VON BENNEWITZ, 2017). In fact, one of the critical factors that limits profitability for smallholders in Latin America is land access (MEDINA et al., 2015).
Vegetable farming has been shown to be a viable option for small farms, generating positive economic impacts and increasing resilience to external risks like climate change. It also has the potential to improve the nutritional quality of the food supply (SCHREINEMACHERS et al., 2018), which is especially relevant considering the high level of over nutrition in Latin America, where nearly a quarter of the population is obese (FAO, 2014; FISBERG et al., 2016).

The benefits of smallholder vegetable production merit studies that help policymakers 
explore ways to promote it. According to FAO (2015), those policies should address farmers' attitudes in addition to their objective situation. Attitudes result from the interaction of affective, cognitive and behavioral factors. Affective factors are feelings or emotions, cognitive factors are thoughts, beliefs and attributes, and behavioral factors relate to past behavior. This subjective approach will assess farmers' evaluation of their business, and, to a large extent, their expected behavior (HADDOCK \& MAIO, 2008).

Analyzing the subjective outlook of farmers, a population characteristic of rural areas, is indispensable to rural psychology. According to LANDINI (2015), rural populations lived experiences, problems and relationships differ from those of city dwellers, and this has been largely ignored and little studied. Rural psychology, therefore, is a discipline that addresses a field of problems that intersect psychology and rurality. Farmers' development strategies and productive practices are a key area for rural psychology research (LANDINI et al., 2010). This research could contribute to agricultural development strategies and rural extension practices. An adequate understanding and management of farmers' context, incorporating a social sciences approach is essential (LANDINI, 2016). Therefore, further understanding of subjective views of farmers in a certain context, such as their attitudes toward their business, allows for more suitable interventions. This research also increases the self-knowledge farmers have about their own community.

Considering the classical concept of "habitus" in BOURDIEU (1984, 1990), views can be deeply tied to their holder's social, economic and cultural context. As a consequence, it can be expected that a group that shares a similar context also shares similar views. Small-scale farmers produce vegetables in a certain region, for example. Small-scale farming is far from completely homogenous, however. According to BERDEGUÉ \& FUENTEALBA (2011), in Latin America, small-scale farming ranges from micro subsistence farms, to market integrated, larger scale producers.

The objective of this research is to characterize the productive and commercial situation of small-scale vegetable growers and, especially, to further understand and explain their attitudes about their business. To that end, we aim to identify the common and differentiating elements of those attitudes between farmers, and to explore if the differences are concomitant to diverse objective characteristics such as age, education, farm size, technological level, etc. Our research takes place in Central Chile, where small-scale farms are prevalent in the production of vegetables, concentrating more than half of the total land (INDAP, 2018).

\section{MATERIALS AND METHODS}

The data analyzed in this article was obtained from a survey conducted between the months of January and February, 2017, of 335 vegetable growers in central Chile, specifically in the Metropolitan Region of Santiago (MRS) and the Region of Libertador Bernardo O'Higgins (O'Higgins). Those regions were selected because they are the most important vegetable production areas in Chile (INE, 2017). Subsequently, the data was validated and coded.

The sample size and its composition were determined by convenience. This nonprobability sampling is suitable when randomization is problematic because the population is too large, and when the objective is to generate an explorative analysis that is not unquestionably generalizable to the whole population (ETIKAN et al., 2016). Randomness of the sample reduces biases, increasing validity of the inference. Nonetheless, convenience sampling can deliver accurate results when the population is homogenous, for instance, if they share the same occupation and location, generalizability increases (JAGER et al., 2017). When the objective is to implement descriptive inference, not casual, the reliability of a non-probabilistic sample for a homogeneous population is high (KOHLER, 2019).

The survey was composed of the following sections: i) personal characteristics of the farmers, ii) socio-demographic profile, iii) technical and production features, iv) access to ICT, innovations and certifications, v) farm management and commercialization and vi) statements regarding attitudes towards their businesses. Single choice, closed questions were used for the items from i) to v). The answers to the last category were formed in accordance with a 5-level Likert scale (1: "completely disagree", 2: "disagree", 3: "indifferent", 4: "agree" and 5: "completely agree").

The information obtained from the survey was first analyzed using descriptive statistics. This was followed by multivariate analysis techniques applied to the results on farmers' attitudes. A principal components factor analysis, which helps reduce the volume of information derived from a large set of variables, was used (JOLLIFFE, 2002). Prior to applying factor analysis, the Bartlett's sphericity 
test and the Kaiser-Meyer-Olkin (KMO) index were estimated in order to determine the sample adequacy for that method (MALHOTRA et al., 2008). After being identified, the variance percentages explained by each of the variables were determined, and the factors were interpreted. The internal consistency of the factors was measured using Cronbach's coefficient alpha. When the factors were established and characterized, a hierarchical clusters analysis was used to define the number of groups to assign, which were specified as two. Considering this result, an analysis of non-hierarchical conglomerates (k-means) was applied for the definition of profiles, which was accompanied by an ANOVA $(\alpha<0.05)$ to identify differentiating views between the groups. Although the ideal sample would be random, the use of parametric tests with convenience samples is widespread in the social sciences (RUTHERFORD, 2001). Finally, each group was characterized by a separate descriptive analysis.

\section{RESULTS}

\section{Descriptive analysis of the sample}

302 men and 33 women were surveyed. The representation of women in this sample is remarkably low, given the estimation that $30 \%$ of farms in Chile are female managed according to the last Agricultural Census of 2007 (QUALITAS, 2010). The gender composition of the sample suggests lower representation of typical female farmer situations, especially in small-scale agriculture. Farms that are managed in order to make production compatible with family life, or that use agriculture to supplement their income, rather than as a main business are typical scenarios for female farm managers (GALIÉ et al., 2013). There is evidence that the continuous tension between reproductive and domestic roles for women in central Chile leads to less productivity and insertion into the labor market when they live with a spouse or partner (FAWAZ \& RODRÍGUEZ, 2013).

The average age of the respondents was 53.3 years old. The migration of youth from rural to urban areas may explain this. According to The World Bank, the Chilean rural population has decreased by $0.8 \%$ annually in the last two decades, while the urban population has increased by $1.5 \%$. This trend is true in central Chile according to CASTRO (2012) and VALDÉS \& REBOLLEDO (2015). The lack of a replacement generation could lead to less interest from farmers in the future of their farms.

$53.34 \%$ of the respondents have only completed elementary school, or have not completed any level of formal education. This is notably higher than the national average. $24.6 \%$ of Chilean adults have completed elementary or less education according to data at the CASEN survey of the Ministry of Social Development for 2017. It is closer to the average for rural population, however. The low level of education might affect their access to technology or innovations.

The average farm size is 10.4 hectares in total, with 7.74 in production. $59.7 \%$ of the farmers rent their land and $35.82 \%$ own it. Almost all production is outdoors. Greenhouses are extremely rare. Furrow irrigation is the most common method. The vast majority use conventional techniques, with a few organic and hydroponic producers.

$84.47 \%$ of the respondents have no offfarm job. The average monthly household income is $1,357,813$ pesos $(1,800.6$ USD, 19-12-2019) and the average farm income is 966,093 pesos $(1,281.14$ USD, 19-12-2019). Both are above the Chilean average household income of 915,484 pesos (1,214.2 USD, 19-12-2019) according with 2017 CASEN Survey. However, there is a wide spread among respondents: the bottom $25 \%$ of the farmers are making less than 400,000 pesos per month (530.5 USD, 19-12-2019) and the bottom $50 \%$ of the farmers are making less than 525,000 pesos per month (696.3 USD, 19-122019). This could be explained by the differences in farm sizes, productivity, types of crops, and access to markets, among other things. Also, there may be differences due to the off-farm income of the households.

Potatoes, onions, garlic, tomatoes and sweet corn were the most common vegetables grown by land area. Intermediaries and wholesalers are the principle commercialization channel for more than half of the respondents, followed by on farm sales and farmers' markets. $73.73 \%$ of the farmers say they are incorporated to the formal economy, meaning their activity is registered at the Internal Revenue Service (Servicio de Impuestos Internos, SII). This is higher than expected, as in Chile the majority of small-scale farmers are informal. One of the main reasons is that they don't see the need to formalize in order to trade or access public funds (BOZA et al., 2018). 48.95\% of respondents have received a subsidy and $62.98 \%$ have received a loan in the last five years, mainly from the National Institute of Agricultural Development (INDAP), the main public institution promoting small-scale farming in Chile. Access to private financing is almost nonexistent. Only $22.98 \%$ of the respondents participate in a farmers' association. 
Use of a computer, email and completing tasks online is low, with $31.34 \%, 23.58 \%$ and $16.71 \%$ of respondents respectively. In contrast, cell phone use is very widespread among the respondents; $95.22 \%$ use them for their business. Not only in Chile, but throughout Latin America, technological change in agriculture has not thoroughly included small-scale producers, especially in information and communication (TRIGO \& ELVERDIN, 2019). Recent innovations made by the respondents were mainly the cultivation of new species, and secondarily on field operation. Although not many respondents had certifications, Good Agricultural Practices (GAP) was the most common.

Assessment of statements referring to attitudes and factorial analysis

In general, farmers find the production techniques they currently employ to be adequate. Techniques were ranked in the following order: soil fertilization (4.24, average score); irrigation (4.05); waste management (4.04); weed control (3.93); and pest and disease control (3.88). Respondents were convinced that they are selling products that are not risky to consumers: "I think my vegetables are safe" (4.82). This result contrasts with expert reports that single out improving food safety as one of the main challenges of Chilean vegetable farming (PERTUZÉ et al., 2019). We suggest that farmers might have difficulty fully understanding the concept of food safety and its implications.

Our results show a low willingness to pay (WTP) for specialized consulting on technical aspects, and even less in management and marketing. These responses may also be influenced by the free or very low cost public extension services that Chilean small-scale farmers receive very frequently, especially from INDAP. The Local Development Program (PRODESAL) is INDAP's most important extension program in terms of coverage and number of beneficiaries (AGUIRRE, 2012). It provides technical assistance and training to family farmers through municipal governments. One of the main characteristics of PRODESAL is its comprehensive approach. As well as supporting farmers on technical issues, the program focuses on socio-economic concerns, such as the health and human capital of the family farm (NAMDAR-IRANI \& SOTOMAYOR, 2011). PRODESAL has no defined exit criteria, which enables farmers to participate for long periods. In general, beneficiaries evaluate the services provided by PRODESAL as very satisfactory (PUC, 2010). In contrast, respondents consider the amount of public support and the related information inadequate: "The available support for vegetable growers is sufficient" (2.51) and "The available information on support instruments is sufficient" (2.44). The perceived lack of public support may seem to contradict the low WTP for private consulting. We suggest that farmers responses might be considering public support not only as consulting and technical support, but more as subsidies and loans for investment. In fact, INDAP divides its programs in two areas: capacitation and funding (INDAP, 2018). Also, previous research has shown a lack of resources for investment to be a key limitation for small-scale farmers in Chile (VON CRAMON-TAUBADEL \& SALDÍAS, 2014; REYES \& LENSINK, 2011).

On commercialization there are differing attitudes. There is clear agreement with the statement: "The sale of my vegetables is made at an appropriate time" (4.56); but indecision, inclining toward disagreement with: "The sale price of my vegetables is good" (2.85). These responses could be due to the high presence of intermediaries. In Chile, the preference for intermediaries results in lower revenues for farmers than more direct sales (AGUIAR et al., 2018). However, Chilean farmers appreciate that intermediaries can buy high volumes at once, and thus provide certain income stability (RIMISP, 2015).

Speaking generally about their business, the results suggest a certain pessimism regarding the future, as the statement "I have a positive vision about the future of my farm" had a low score (2.96). This might be related to the old age of the farmers and the lack of a replacement generation. In contrast, there is agreement on the current contribution that farm income makes to their households: "I believe that the income generated by my farm allows my family to have access to a good quality of life" (4.06). They are slightly less enthusiastic regarding the time required to obtain that income: "I consider that the time that I work on my farm is adequate" (3.78).

The principal component analysis based on answers to the proposed statements showed that the farmers' attitudes could be explained as $57.89 \%$ of the variance for the following four factors: "technical and productive aspects" (18.69\%), "support instruments and quality" (15.83\%), "willingness to pay for advisory" $(13.7 \%)$ and "general view of the activity" (9.67\%). Their specific composition is detailed in table 1 .

Cluster analysis of vegetable growers in terms of their attitudes

Two homogenous groups of farmers were identified in terms of their attitudes (Table 2). 
Table 1 - Composition of factors which explain farmers' attitudes.

\begin{tabular}{|c|c|c|c|}
\hline Factor & $\begin{array}{l}\% \text { of } \\
\text { variance }\end{array}$ & Weight & Factor variable \\
\hline \multirow{5}{*}{$\begin{array}{l}\text { Technical and } \\
\text { productive } \\
\text { aspects }\end{array}$} & \multirow{5}{*}{$18.69 \%$} & 0.845 & I consider my pest and disease control techniques adequate \\
\hline & & 0.814 & I consider my weed control techniques adequate \\
\hline & & 0.753 & I consider my soil fertilization techniques adequate \\
\hline & & 0.711 & I consider my irrigation techniques adequate \\
\hline & & 0.539 & I consider my waste management techniques adequate \\
\hline \multirow{4}{*}{$\begin{array}{l}\text { Support } \\
\text { instruments } \\
\text { and quality }\end{array}$} & \multirow{4}{*}{$15.83 \%$} & 0.868 & The available support for the vegetable growers is sufficient \\
\hline & & 0.750 & The available information on support instruments is sufficient \\
\hline & & 0.688 & The sale price of my vegetables is good \\
\hline & & -0.606 & I think my vegetables are safe \\
\hline \multirow{3}{*}{$\begin{array}{l}\text { Willingness to } \\
\text { pay for } \\
\text { advisory }\end{array}$} & \multirow{3}{*}{$13.7 \%$} & 0.842 & I am willing to pay for specialized advice on marketing \\
\hline & & 0.839 & I am willing to pay for specialized advice on management \\
\hline & & 0.724 & I am willing to pay for specialized advice on production \\
\hline \multirow{4}{*}{$\begin{array}{l}\text { General view } \\
\text { of the activity }\end{array}$} & \multirow{4}{*}{$9.67 \%$} & 0.714 & I consider that the time that I work on my farm is adequate \\
\hline & & -0.642 & I have a positive vision of the future of my business \\
\hline & & 0.604 & $\begin{array}{l}\text { I believe that the income generated by my farm allows my family to have } \\
\text { access to a good quality of life }\end{array}$ \\
\hline & & 0.586 & The sale of my vegetables is made at an appropriate time \\
\hline
\end{tabular}

These groups were named: "conformist" (69.05\%) and "critical" (30.95\%). The first is defined by its relatively positive attitude, particularly in terms of their conformity with their current technical and productive practices and general view of their business. One possible consequence of this is the negative WTP of this segment for technical consultation, as they might not consider it necessary. In contrast, the "critical" segment was characterized by its all-round negative attitude toward the current reality of their business and higher willingness to pay for consultation.

To summarize, there is a smaller but relevant segment of farmers who are skeptical about all aspects of their business, so they are receptive to receive advice, even if they must pay for it. "Conformist" farmers, meanwhile, present more positive attitudes in terms of the present and future of their activity, and don't consider it necessary to pay for advice.

There are some relevant differences in the makeup of the clusters. The "conformist" segment is made up of considerably older producers, with an average age of 54, while the "critical" group was 46.4 years old on average. Previous research is consistent with this result, showing that farmers' willingness to change worsens with age (SEVINÇ et al., 2019; DHRAIEF et al., 2019). KATANO et al. (2019) show that elder small-scale farmers have traditional outlook and values, rather than economically logical

Table 2 - Farmers' clusters in terms of attitudes towards their activity.

\begin{tabular}{lcc}
\hline Components & "Conformist” N $=231$ & "Critical" $\mathrm{N}=104$ \\
\hline Technical and productive aspects & 0.38807 & -0.86570 \\
Support instruments and quality & 0.17797 & -0.39701 \\
Willingness to pay for advisory & -0.08010 & 0.17869 \\
General view of the activity & 0.36121 & -0.80577 \\
\hline
\end{tabular}

Ciência Rural, v.50, n.10, 2020. 
ones. The participants in the "conformist" segment had relatively lower levels of education, with $60.1 \%$ of the respondents having finished only elementary school or no formal education, compared to only $34.4 \%$ in the "critical" profile. In the "critical" segment, the majority of farmers have secondary, technical or even university education. The level of education determines the capability of small-scale farmers to incorporate more efficient technologies into their operation (WU, 2020; DHRAIEF et al., 2019; NGANGO \& KIM, 2019).

Vegetable growers in the "critical" profile have a larger average farm size, both in total and productive hectares. They are the only ones using organic and hydroponic techniques, and use less furrow irrigation. The average sale per hectare is also higher for the "critical" farmers. Research has shown that for small-scale farmers in Chile, the value of production is positively related to farm size (BOZA \& JARA-ROJAS, 2018), and we suggest that a more entrepreneurial vision is also related.

$24.2 \%$ of the "critical" farmers also have an off-farm job, compared to $10 \%$ of the "conformist" segment. We suggest that older age of "conformist" farmers hinders their ability to get a job. Research in central Chile has shown that off-farm jobs increase small-scale farmers adaptability to external risks such as climate change (FERNÁNDEZ et al., 2019). This might be due to the ability to generate different economic strategies, shifting and combining income sources as needed. Although innovation in general is low, the producers in the "critical" cluster have a somewhat higher level. The use of the internet is also higher in the "critical" segment. In Chile, even if small-scale farmers understand the importance of ICTs to improve their competitiveness, many of them do not know how to use them (MORA et al., 2012). We suggest that the older, less educated farmers in our sample are less likely to have these skills, and as a consequence they are less able to incorporate ICTs.

"Conformist" farmers are more likely to participate in technical-productive associations. Farmers in that group also benefit more from public programs, including obtaining financial resources, than those at the "critical" cluster. We suggest that both participation in associations and public programs might be related. In Chile, farmers who are beneficiaries of INDAP's PRODESAL are organized in Communal Operating Units (COUs) with other similar, nearby farmers. COUs are groups that serve as spaces for participation, coordination and dialogue (RAMÍREZ et al., 2014). Other INDAP extension programs, such as the Technical Advisory Service, also group farmers in operational units (BERDEGUÉ, 2018). The farmers in our survey may be identifying INDAP's groups as an association to which they belong.

\section{CONCLUSION}

The small-scale vegetable farmers surveyed are characterized by a high average age, low level of education, a wide range of farm sizes and household incomes, low levels of innovation, especially nontechnical innovation, commercialization mainly through intermediaries, and limited interaction with the public sector and with other farmers. They evaluate their technical operation and the food safety of their products positively. On commercialization, they like their ability to sell in a timely manner, but not the price they receive. They think government support is not sufficient, but their WTP for consulting is low. They are uncertain about the future of their farms, but they think it is an important contribution to their families' well-being. These attitudes were summarized into four factors: "technical and productive aspects," "support instruments and quality," "WTP for advisory," and "general view of the activity".

We identified two clusters among the respondents: "conformist" (69.05\% of the sample) and "critical" $(30.95 \%)$. The first has a positive outlook on both their current situation and the future of the farm. This may explain why they are not willing to pay for consulting. The second are critical about their businesses, but they are receptive to advice, even if they must pay for it. There are significant differences in the objective characteristics of the members of each cluster. "Conformist" farmers are older and less educated. Their farms are smaller, their sale per hectare is lower, they are less innovative and limited in the use of ICTs. They seem to be more interested in collective action, as they participate more in associations and public programs.

These findings are coherent with our initial assumption: small-scale vegetable growers share certain attitudes in general, but disagree on some topics. The differences in attitudes coincide with differences in their objective characteristics, including age, education, farm size, technology, etc. In any case, these findings are exploratory and not completely generalizable, as our sample although homogenous was not probabilistic. Regardless, they are useful as a preliminary approach, and policymakers can use them to aid in the design and execution of interventions adapted to the different farmer profiles. For instance, "critical" farmers should be approached 
with individual intervention, and "conformist" farmers collectively and in stages, to convince them of the benefits of improving, without facing as much resistance to change.

\section{ACKNOWLEDGEMENTS}

This research was developed within the "Horticultural Extension Center" project funded by the INNOVA-CORFO "Technological Extension Center" grant, "Healthy Foods" line. The authors also thank the professionals who collaborated in the survey application.

\section{BIOETHICS AND BIOSSECURITY COMMITTEE APPROVAL}

We the authors of the article entitled "Characteristics and attitudes of small-scale vegetable farmers in Chile "declare, for all due purposes, the project that gave rise to the data presented has not been submitted for evaluation to the Ethics Committee of the University of Chile, but we are aware of the contents of Resolution No. 466, of December 12, 2012 of the Brazilian National Health Council "http://conselho.saude.gov.br/resolucoes/2012/Reso466. pdf" if it involves humans.

Thus, the authors assume full responsibility for the presented data and are available for to respond to questions should they be required by the relevant authorities.

\section{DECLARATION OF CONFLICT OF INTERESTS}

The authors declare no conflict of interest. The founding sponsors had no role in the design of the study; in the collection, analyses, or interpretation of data; in the writing of the manuscript, and in the decision to publish the results.

\section{AUTHORS' CONTRIBUTIONS}

The authors contributed equally to the manuscript.

\section{REFERENCES}

AGUIAR, L. Da C.; et al., Short food supply chain: characteristics of a family farm. Ciência Rural, 21 May. 2018. v.48, n.5. Available from: $<$ http://www.scielo.br/scielo.php?script $=$ sci arttext\&pid $=$ S0103-84782018000500800\&lng=en\&tlng=en $>$. Accessed: Jul. 24, 2019.

AGUIRRE, F. El Nuevo Impulso de la Extensión Rural en América Latina Situación actual y perspectivas. Santiago de Chile: Red Latinoamericana para los Servicios de Extensión Rural, 2012. Available from: <http:/www.redinnovagro.in/ documentosinnov/nuevoimpulso.pdf $>$. Accessed: May, 2, 2020

BERDEGUÉ, J. Innovations in financing mechanisms for demanddriven agricultural advisory services. Innovations in financing mechanisms for demand-driven agricultural advisory services The Chile case, 1978-2014. Rome: [s.n.], 2018.

BERDEGUÉ, J. A.; FUENTEALBA, R. The state of smallholders in agriculture in Latin America. New Directions for Smallholder Agriculture, 2011. p.115-152.
BOURDIEU, P. Distinction : a social critique of the judgement of taste. First ed. Paris: Routledge, 1984.

The Logic of Practice. Reprint ed. Stanford, California: Stanford U.P., 1990.

BOZA, S. et al. Family farmers' reluctance toward incorporating into the formal economy. Economía Agraria y Recursos Naturales, 4 Jan. 2018. v.18, n.2, p.75. Available from: $<$ https://polipapers.upv.es/index. php/EARN/article/view/earn.2018.02.04> . Accessed: Jul. 25, 2019.

BOZA, S.; JARA-ROJAS, R. Peri-urban family farming and agricultural earnings: The effect of long-term participation in an extension program in a metropolitan area. Ciencia e Investigacion Agraria, 2018. v.45, n.3, p.200-209. Available from: <https:// scielo.conicyt.cl/scielo.php? script $=$ sci_abstract\&pid $=$ S071816202018000300200\&lng=en\&nrm $=$ iso $>$. Accessed: May, 2, 2020. doi: 10.7764/rcia.v45i3.1783.

CASTRO, A. Familias rurales y sus procesos de transformación: Estudio de casos en un escenario de ruralidad en tensión. Psicoperspectivas, 2012. v.11, n.1, p.180-203. Available from: $<$ https://www.psicoperspectivas.cl/index.php/psicoperspectivas/ article/view/172>. Accessed: May, 2, 2020. doi: 10.5027/ PSICOPERSPECTIVAS-VOL11-ISSUE1-FULLTEXT-172.

DHRAIEF, M. Z. et al. Factors affecting innovative technologies adoption by livestock holders in arid area of Tunisia. New Medit, 2019. v.18, n.4, p.3-18. Available from: <https://newmedit.iamb. it/2019/11/08/factors-affecting-innovative-technologies-adoptionby-livestock-holders-in-arid-area-of-tunisia/>. Accessed: May, 2, 2020. doi: $10.30682 / \mathrm{nm} 1904 \mathrm{a}$.

ETIKAN, I.; MUSA, S. A.; ALKASSIM, R. S. Comparison of Convenience Sampling and Purposive Sampling. American Journal of Theoretical and Applied Statistics, 2016. v.5, n.1, p.1-4. Available from: <http://www.sciencepublishinggroup. $\mathrm{com} / \mathrm{journal} /$ paperinfo? journalid $=146 \& \mathrm{doi}=10.11648 / \mathrm{j}$. ajtas.20160501.11>. Accessed: Dec. 11, 2019. doi: 10.11648/j. ajtas.20160501.11.

FAO. Understanding smallholder farmer attitudes to commercialization. The case of maize in Kenya. (A. Woolverton \& D. Neven, Eds.). Rome: FAO, 2014. Available from: <www.fao. org/publications>. Accessed: Dec. 23,2019.

Promotion of Fruit and Vegetables for Health. Rome: FAO, 2015. Available from: <http://www.fao.org/3/a-i4935e.pdf $>$. Accessed: Dec. 23, 2019.

FAWAZ-YISSI, M. J.; RODRÍGUEZ-GARCÉS, C. Mujeres rurales y trabajo en Chile central. Actitudes, factores y significaciones. Cuadernos de Desarrollo Rural, 2013. v.10, n.72, p.47-68. Available from: <http://www.scielo.org.co/pdf/cudr/v10n72/ v10n72a04.pdf $>$. Accessed: May, 2,2020.

FERNÁNDEZ, F. J. et al. Implications of climate change for semiarid dualistic agriculture: a case study in Central Chile. Regional Environmental Change, 2019. v.19, n.1, p.89-100. Available from: $\quad<$ https://link.springer.com/article/10.1007/s10113-0181380-0\#citeasf $>$. Accessed: May, 2, 2020. doi: 10.1007/s10113018-1380-0.

FISBERG, M. et al. Latin American Study of Nutrition and Health (ELANS): Rationale and study design. BMC Public Health, 30 Jan. 2016. v.16, n.1. Available from: <https://bmcpublichealth.

Ciência Rural, v.50, n.10, 2020. 
biomedcentral.com/articles/10.1186/s 12889-016-2765-y>. Accessed: May, 2, 2020. doi: 10.1186/s12889-016-2765-y.

GALIÈ, A.; JIGGINS, J.; STRUIK, P. C. Women's identity as farmers: A case study from ten households in Syria. NJAS Wageningen Journal of Life Sciences, 1 Sep. 2013. v.64-65, p.25-33. Available from: $<$ https://www.sciencedirect.com/science/ article/pii/S1573521412000541>. Accessed: May, 2, 2020. doi: 10.1016/j.njas.2012.10.001

HADDOCK, G.; MAIO, G. Attitudes: Content, structure and functions. In: HEWSTONE, M.; STROEBE, W.; JONAS, K. (Eds.). Introduction to social psychology: A European perspective. BPS textbo ed. Oxford: [s.n.], 2008, p. 112-133.

INDAP. INDAP en cifras 2017. Santiago. Chile: INDAP, 2018. Available from: <https://www.indap.gob.cl/biblioteca/ documentos-indap/!k/indap-en-cifras-(primer-semestre-2017)>. Accessed: Dec. 11, 2019.

INE. Presentación entrega de resultados preliminares Censo 2017. Santiago. Chile.: [s.n.], 2017. Available from: <http:// www.censo2017.cl/wp-content/uploads/2017/08/ProcesoCensal-Resultados-preliminares-31-08-2017.pdf.>. Accessed: Dec. 11, 2019.

JAGER, J.;et al.,. More than Just Convenient: The Scientific Merits of Homogeneous Convenience Samples. Monographs of the Society for Research in Child Development, 1 Jun. 2017. v.82, n.2, p.13-30. Available from: <https://www.ncbi.nlm.nih. gov/pubmed/28475254>. Accessed: May, 2, 2020. doi: 10.1111/ mono. 12296

JOLLIFFE, I. Principal Component Analysis. Second ed. New York: Springer-Verlag New York, 2002.

KOHLER, U. Possible Uses of Nonprobability Sampling for the Social Sciences. Survey Methods: Insights from the Field, 2019. p. 1-12. Available from: $<$ https://surveyinsights.org/?p=10981>. Accessed: May, 2, 2020. doi: 10.13094/SMIF-2019-00014.

KATANO, Y; et al.,Traditional or Economic Values? Analyzing Absentee Landowner Attitudes Amid Social and Agricultural Transformation in Japan. Rural Sociology, 2019. p.1-24. Available from: $<$ https://onlinelibrary.wiley.com/doi/abs/10.1111/ ruso.12310>. Accessed: May, 2, 2020. doi: 10.1111/ruso.12310.

LANDINI, F. Hacia una psicología rural Latinoamericana. Buenos Aires: CLACSO, 2015.

How to be a good rural extensionist. Reflections and contributions of Argentine practitioners. Journal of Rural Studies, 2016. v.43, p.193-202. Available from: <https://www. sciencedirect.com/science/article/abs/pii/S0743016715300504>. Accessed: May, 2, 2020. doi: 10.1016/j.jrurstud.2015.11.014.

BENÍTEZ, M. I.; MURTAGH, S. Revisión de los

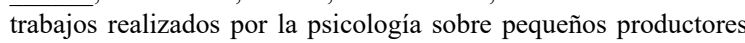
agropecuarios. Jornadas de Investigación Psicología, 2010. v. XVII, p. 221-229. Available from: <https://www.redalyc.org/ articulo.oa?id=369139946012>. Accessed: May, 2, 2020 .

LOWDER, S. K; et al.,The Number, Size, and Distribution of Farms, Smallholder Farms, and Family Farms Worldwide. World Development, 1 Nov. 2016. v.87, p.16-29. Available from: $\quad<$ https://www.sciencedirect.com/science/article/pii/
S0305750X15002703>. Accessed: May, 2, 2020. doi: 10.1016/j. worlddev.2015.10.041

MALHOTRA, N. K.; et al., Investigación de mercados. Prentice H ed. México DF.: Pearson Educación, 2008.

MEDINA, G. et al. Development conditions for family farming: Lessons from Brazil. World Development, 1 Oct. 2015. v.74, p.386-396. Available from: <https://www.sciencedirect.com/ science/article/pii/S0305750X15001412>. Accessed: Jul. 23, 2019. doi: 10.1016/j.worlddev.2015.05.023.

MORA, M et al. Innovation requirements for the development of cactus pear for export: A new item to be incorporated to the chilean fruit export sector. Acta Horticulturae, 2013. v.995, p.229-236. Available from: <https://www.ishs.org/ishs-article/995_27>. Accessed: Jul. 23, 2019. doi: 10.17660/actahortic.2013.995.27.

MORA, et al. Definición de las brechas en el uso de las tic's para la innovación productiva en PYMES del sector pecuario chileno. Journal of Technology Management and Innovation, 2012. v.7, n.2, p.171-182. Available from: $<$ https://scielo.conicyt.cl/scielo.php?script=sci_arttext\&pid $=$ S0718-27242012000200014 $>$. Accessed: Jul. 23, 2019. doi: $10.4067 / \mathrm{s} 0718-27242012000200014$

NAMDAR-IRANI, M.; SOTOMAYOR, O. Le conseil agricole au Chili face à la diversité des agriculteurs. Cahiers Agricultures, 2011. v.20, n.5, p.352-358.

NGANGO, J.; KIM, S. G. Assessment of technical efficiency and its potential determinants among small-scale coffee farmers in Rwanda. Agricultural- Basel, 2019. v.9, n.7, p.1-12.

PERTUZÉ CONCHA, R. et al. Producción y comercialización de hortalizas en la Región de Aysén. Libro de Valorización. Santiago: Fundación para la Innovación Agraria- Universidad de Chile, 2019.

PUC. Evaluación de Impacto. Informe Final: Programa De Desarrollo Local (PRODESAL) y Programa De Desarrollo De Comunas Pobres (PRODECOP). Santiago, Chile: Pontificia Universidad Católica de Chile, 2010

QUALITAS. Estudio de Caracterización de la Pequeña Agricultura a partir del VII Censo Nacional Agropecuario y Forestal. Santiago, Chile: Qualitas/Indap, 2010. Available from: $<$ https://www.agroqualitas.cl/publicaciones_2/estudio-decaracterizacion-de-la-pequena-agricultura-a-partir-del-vii-censonacional-agropecuario-y-forestal/>. Accessed: May, 2, 2020.

RAMÍREZ, E. et al. Evaluación de programas de INDAP. Santiago, Chile: Agraria, 2014

RUTHERFORD. A. Introducing Anova and Ancova: A GLM Approach. London: SAGE Publications Inc, 2001.

SCHREINEMACHERS, P.; et al.,Tapping the economic and nutritional power of vegetables. Global Food Security, 1 Mar. 2018. v.16, p.36-45. Available from: $<$ https://www.sciencedirect. com/science/article/pii/S2211912417300640>. Accessed: May, 2, 2020. doi: 10.1016/j.gfs.2017.09.005.

SEVINÇ, G. et al. Farmers' attitudes toward public support policy for sustainable agriculture in GAP-Sanliurfa, Turkey. Sustainability (Switzerland), 2019. v.11, n.23. Available from: $<$ https://www.mdpi.com/2071-1050/11/23/6617>. Accessed: May, 2, 2020. doi: $10.3390 /$ su11236617.

Ciência Rural, v.50, n.10, 2020. 
REYES, A.; LENSINK, R. The credit constraints of marketoriented farmers in Chile. Journal of Development Studies, Dec. 2011. v.47, n.12, p.1851-1868. Available from: <https:// www.tandfonline.com/doi/abs/10.1080/00220388.2011.579111>. Accessed: May, 2 2020. doi: 10.1080/00220388.2011.579111.

RIMISP. Agricultura familiar y circuitos cortos en chile: situación actual, restricciones y potencialidades. Santiago de Chile: Centro Latinoamericano Para el Desarrollo Rural, 2015. Available from: <www.odepa.gob.cl>. Accessed: Jul. 23, 2019.

TRIGO, E. J.; ELVERDIN, P. Los sistemas de investigación y transferencia de tecnología agropecuaria de América Latina y el Caribe en el marco de los nuevos escenarios de ciencia y tecnología. 2030 - Alimentación, agricultura y desarrollo rural en América Latina y el Caribe. Santiago, Chile: FAO, 2019. Available from: <http://www.fao.org/publications/es>. Accessed: Apr. 1, 2020.

VALDÉS, X.; REBOLLEDO, L. Géneros, generaciones y lugares: cambios en el medio rural de Chile Central. Polis, Revista Latinoamericana, 2015. v.14, n.42, p.491-513. Available from: $\quad<$ http://dx.doi.org/10.4067/S0718-65682015000300022>. Accessed: May, 2 2020. doi: 10.4067/S0718-65682015000300022.

VON BENNEWITZ, E. Land tenure in Latin America: from land reforms to counter-movement to neoliberalism. Acta Universitatis Agriculturae et Silviculturae Mendelianae Brunensis, 2017. v.65, n.5, p.1793-1798. Available from: <https://acta.mendelu.cz/65/5/1793/>. Accessed: Dec. 23, 2019. doi: 10.11118/actaun201765051793.

VON CRAMON-TAUBADEL, S.; SALDIAS, R. Access to credit and determinants of technical inefficiency of specialized smallholder farmers in chile. Chilean Journal of Agricultural Research, 1 Dec. 2014. v.74, n.4, p.413-420. Available from: <http://dx.doi. org/10.4067/S0718-58392014000400006>. Accessed: May, 2, 2020. doi: $10.4067 /$ S0718-58392014000400006.

WU, W. Estimation of technical efficiency and output growth decomposition for small-scale rice farmers in Eastern India: A stochastic frontier analysis. Journal of Agribusiness in Developing and Emerging Economies, 2020. Available from: <https://www.emerald.com/insight/content/doi/10.1108/ JADEE-05-2019-0072/full/html>. Accessed: May, 2, 2020. doi: 10.1108/JADEE-05-2019-0072. 